\title{
Distinctive prokaryotic microbiomes in sympatric plant roots from a Yucatan cenote
}

\author{
Alejandra Escobar-Zepeda ${ }^{1 \dagger}$, Patricia Rosas-Escobar ${ }^{2 \dagger}$, Laura Marquez Valdelamar ${ }^{2}$, Patricia de la Torre ${ }^{3}$, \\ Laila P. Partida-Martinez ${ }^{4}$, Ruben Remegaldo ${ }^{5}$, Alejandro Sanchez-Flores ${ }^{1 *}$ and Fredd Vergara ${ }^{6,7^{*}}$ (D)
}

\begin{abstract}
Objective: Cenotes are flooded caves in Mexico's Yucatan peninsula. Many cenotes are interconnected in an underground network of pools and streams forming a vast belowground aquifer across most of the peninsula. Many plants in the peninsula grow roots that reach the cenotes water and live submerged in conditions similar to hydroponics. Our objective was to study the microbial community associated with these submerged roots of the Sac Actun cenote. We accomplished this objective by profiling the root prokaryotic community using 165 rRNA gene amplification and sequencing.

Results: We identified plant species by DNA barcoding the total genomic DNA of each root. We found a distinctive composition of the root and water bacterial and archaeal communities. Prokaryotic diversity was higher in all plant roots than in the surrounding freshwater, suggesting that plants in the cenotes may attract and select microorganisms from soil and freshwater, and may also harbor vertically transmitted lineages. The reported data are of interest for studies targeting biodiversity in general and root-microbial ecological interactions specifically.
\end{abstract}

Keywords: 16S rRNA, Cenote, Ficus obtusifolia, Gliricidia sepium, Taxonomic profiling, Rhizosphere, Trichilia hirta

\section{Introduction}

The Yucatan peninsula in Southeastern Mexico presents a characteristic landscape devoid of high mountains and aboveground rivers. The peninsula is a partially emergent carbonate platform where Mesozoic- and Cenozoic-era limestone, dolomite, and anhydrite overlie deeply buried Paleozoic-era crystalline and sedimentary rocks [1]. The main inland ecosystems are evergreen and deciduous tropical forests [2] and the mean precipitation in the peninsula is approx. $1200 \mathrm{~mm}$ per annum [3] (Fig. 1).

\footnotetext{
*Correspondence: alexsf@ibt.unam.mx; fredd.vergara@idiv.de; fredd@unam. $\mathrm{mx}$

${ }^{\dagger}$ Alejandra Escobar-Zepeda and Patricia Rosas-Escobar contributed equally to this work

${ }^{1}$ Instituto de Biotecnologia, Unidad Universitaria de Secuenciacion

Masiva Y Bioinformatica, Universidad Nacional Autonoma de Mexico, Cuernavaca, Mexico

${ }^{6}$ Molecular Interaction Ecology/EcoMetEoR, German Centre

for Integrative Biodiversity Research Halle-Jena-Leipzig, Leipzig, Germany

Full list of author information is available at the end of the article
}

Rainwater rapidly percolates and dissolves the porous, karstic bedrock forming large cavities [4]. In some cases, the walls of these caves collapse leaving behind sinkholes locally known with the Mayan name of cenotes. Rainwater accumulates in the cenotes, many of which are interconnected in an underground network of pools and streams that form a vast belowground aquifer across most of the peninsula [5]. The water contained in the cenotes is the only year-round reliable source of fresh water in this region and thus, the cenotes have influenced the development of human civilization, but also other species including plant communities [6]. In the case of plants, roots penetrate the cenotes' ceiling rocks, which sometimes can be several meters wide, to reach freshwater reservoirs inside the cenotes. These roots remain immersed in the freshwater, resembling a hydroponic system.

Bacterial microbiomes and their role in plant roots have been extensively studied in terrestrial ecosystems.

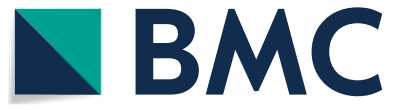

(c) The Author(s) 2021. Open Access This article is licensed under a Creative Commons Attribution 4.0 International License, which permits use, sharing, adaptation, distribution and reproduction in any medium or format, as long as you give appropriate credit to the original author(s) and the source, provide a link to the Creative Commons licence, and indicate if changes were made. The images or other third party material in this article are included in the article's Creative Commons licence, unless indicated otherwise in a credit line to the material. If material is not included in the article's Creative Commons licence and your intended use is not permitted by statutory regulation or exceeds the permitted use, you will need to obtain permission directly from the copyright holder. To view a copy of this licence, visit http://creativecommons.org/licenses/by/4.0/. The Creative Commons Public Domain Dedication waiver (http://creativeco mmons.org/publicdomain/zero/1.0/) applies to the data made available in this article, unless otherwise stated in a credit line to the data. 

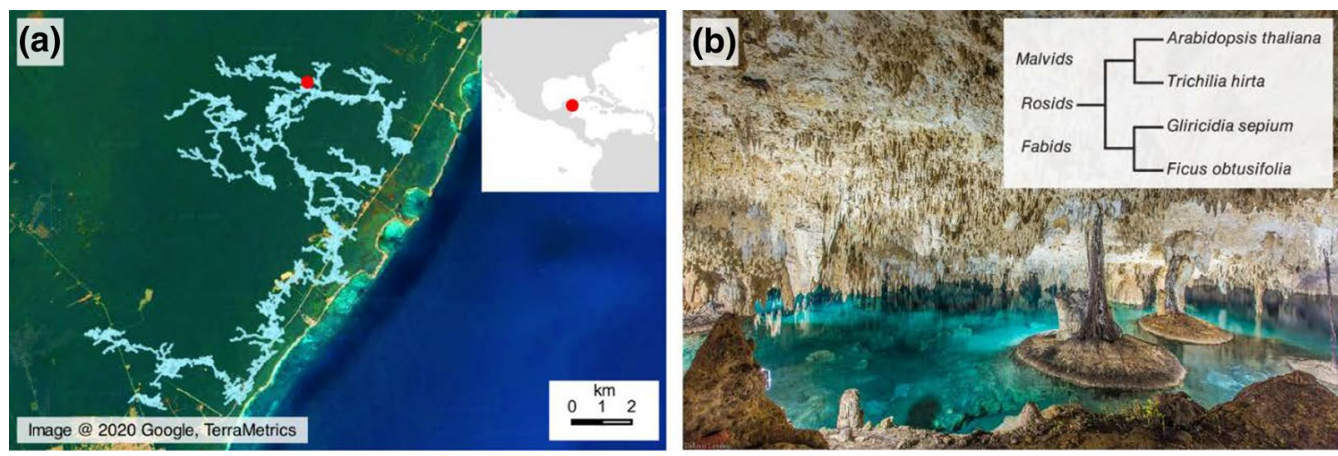

Fig. 1 Sampling site in the Yucatan peninsula, Mexico. (a) The location of the Sac Actun cenote is highlighted in red and the currently surveyed extension of the local underground cave system is shown in blue [15]. The high-resolution basemap was obtained through Google earth and the continental delineation originates from the Database of Global Administrative Areas v3.6 (GADM). (b) Photograph of the sampling site (https:// search.creativecommons.org/photos/fd1 d5a63-ae74-457a-944b-a4c3521 c232f). The insert shows a cladogram with the phylogenetic relationship of the plant species investigated in reference to $A$. thaliana. We used DNA barcoding for plant species identification

For example, in terrestrial-only ecosystems, plant roots interact with a multitude of microorganisms in the soil, which provide nutrients and are involved in nitrogen fixation. Also, root associated soil microbial communities participate in plant nutrition, development and immunity, as well as in tolerance to several types of biotic and abiotic stresses. Correspondingly, the plant innate immune system must simultaneously tolerate beneficial microbes to survive while limiting the growth of potential pathogens [7]. However, for plants with steady waterimmersed roots, the microbial-root interaction remains understudied. The data we provide in this report contributes to expand our knowledge of root microbe interactions under in a freshwater environment.

\section{Main text}

\section{Materials and methods}

\section{Sample collection and pre-processing}

Roots and fresh water from three plants were collected in the Sac Actun cenote $\left(20^{\circ} 19^{\prime} 49^{\prime \prime} \mathrm{N} 87^{\circ} 24^{\prime} 13^{\prime \prime} \mathrm{W}\right)$ in Yucatan, Mexico in April, 2013. Roots were not in physical contact with each other and separated 5 to $10 \mathrm{~m}$. Roots were collected at a depth of 30 to $50 \mathrm{~cm}$ from the air/water interface. Samples were immediately placed on ice and air-transported to Universidad Nacional Autonoma de Mexico in Mexico City. Upon arrival, samples were freeze-dried and kept at $-80{ }^{\circ} \mathrm{C}$ until further processing.

\section{Plant species identification by DNA barcode}

Total genomic DNA was isolated from freeze-dried roots using the Qiagen Dneasy plant kit following manufacturer's protocol. All amplifications were performed in a 2720 thermal cycler (Applied Biosystems) with 40-50 ng of DNA, $1 \times$ PCR buffer, $2 \mathrm{mM} \mathrm{MgCl} 2,1.6 \mu$ g bovine serum albumin (BSA), $200 \mu \mathrm{M}$ of each dNTP, $0.12 \mu \mathrm{M}$ of each primer and $0.625 \mathrm{U}$ of Taq Platinum polymerase (Invitrogen) in $25 \mu \mathrm{L}$ total volume. Primers recommended by the Plant Working Group of the Consortium for the Barcode of Life (http://www.boldsystems.org) were used to amplify four different genome regions (Additional file 3: Table S2). Amplicons were confirmed by electrophoresis on a $1 \%$ agarose gel and further purified with sephadex columns (GE Healthcare Life Sciences) following user's manual. Purified PCR products were bidirectionally sequenced using the original PCR primers with the BigDye v3.1 on an ABI 3500xL genetic analyzer (Applied Biosystems). Sequences were pre-processed with Sequencing Analysis Software v6.0 (Applied Biosystems) and further edited and assembled with Sequencher v5.0.1 (Gene Codes Corporation). Individual sequences were blasted against databases hosted in the National Center for Biotechnology Information (NCBI) and the Barcode of Life Data Systems (BOLD) for species identification. For plant species identification, a total of $553 \mathrm{bp}$ were obtained for the $r b c L$ region, $808 \mathrm{bp}$ for $m a t K$ and $402 \mathrm{bp}$ for trnH-psbA. For the first sample, BLAST results obtained for the three regions showed the most similar genus was Ficus (Moraceae). However, it was not possible to infer the species because $99 \%$ identity resulted in more than one species, but using only the trnH-psbA marker, we obtained $100 \%$ of identity hit to Ficus obtusifolia. For the second sample for $r b c L$ a total of $100 \%$ of similarity was found for Trichilia (Meliaceae) and 99\% to Dysoxylum, Heckeldora, Leplaea, Chisocheton, Turreanthus, Walsura, Vavaea and Guarea genera, but these genera are not reported for Mexico. Also, for matK $99 \%$ of similarity was found for Trichilia. To achieve species level identification, a sample of two specimens ( $T$. hirta: MEXU 1,167,324 and T. havanensis: MEXU 1,024,025) 
from National Herbarium of Mexico (MEXU) were used. DNA of these samples was extracted using standard method for plants [8]. rbcL and matK regions were amplified using primers in Additional file 3: Table S2 and sequenced. Comparing the sample against $T$. hirta and $T$. havanensis, $100 \%$ of identity was found against T. hirta. For the third sample, BLAST results for $r b c L$ and matK markers reported $100 \%$ of identity to Gliricidia sepium (Fabaceae), and $99 \%$ of similarity for G. sepium and G. maculate, respectively. For the latter marker, both result names are synonymous, so the species was considered as G. sepium. Cladogram in Fig. 1 was generated based on the plant lineages using the ETE3 package [9]. GenBank accession numbers are shown in Additional file 3: Table S3.

\section{S rRNA sequencing using lon Torrent Technology}

For DNA isolation, the roots were macerated in $50 \mathrm{ml}$ of sterile distilled water. Subsequently, the supernatant was passed through a $0.45 \mu \mathrm{m}$ filter (Merck Millipore Corporation). With this filtrate, DNA extraction was continued using the Power Water DNA isolation kit (MoBio Laboratories Inc., Carlsbad, CA, USA). DNA quality and quantity was evaluated by electrophoresis and using a Nanodrop (1000) (Thermo Scientific). 16S $r$ RNA gene amplification was carried out using the Ion $16 \mathrm{~S}^{\mathrm{TM}}$ Metagenomics Kit (Life Technologies) following the manufacturer's protocol using two primer pools to amplify seven hypervariable regions (V2, V3, V4, V6, V7, V8, and V9) of bacterial 16S $r$ RNA. $2 \mu \mathrm{L}$ of each sample were needed along with the Ion Xpress Barcode Adapters 1-16 Kit (Life Technologies, Carlsbad, CA, USA). For library construction the Ion Plus Fragment Library kit (Life Technologies) was used following manufacturer protocol. Quality of samples was evaluated in an Agilent Bioanalyzer 2000 with Agilent High Sensitivity DNA kit (Agilent Technologies). Library concentration was measured with a qPCR using the Ion Universal Library Quantitation Kit in a Step One Real-Time PCR System (Applied Biosystems). Samples were adjusted to $10 \mathrm{mM}$ final concentration. PCR was conducted on an Ion One Touch 2 using the Ion PGMTM Template OT2 400 (Life Technologies), and Sequencing on an Ion PGM using an Ion $310 \mathrm{v} 2$ chip, following manufacturer's protocol.

\section{S rRNA sequences processing and analyses}

For bacterial taxonomic profiling, the 16S $r$ RNA amplicon reads raw reads were analyzed using Perl scripts (https://github.com/Ales-ibt/16S_processing). Sequences were filtered by length $<50 \mathrm{bp}$ and identical sequences were dereplicated through the -derep_fulllength function from VSEARCH tool v2.4.3 [10]. Unique sequences were clustered at $97 \%$ of sequence identity (OTUs 0.03 ) by the -cluster_fast function. To discard artificial diversity, we followed a filtering strategy of chimeric sequences detection using the -uchime_denovo function. Additionally, the clusters of size 1 represented in one sample only were discarded from the OTU table, as well as all those sequences which annotation did not match to Bacteria or Archaea domains. The final OTU table was rarefied to 53,659 reads using the rrarefy function from the R Vegan library v2.4-6 to calculate alpha diversity. We calculated the Chao1 richness estimator and the Shannon diversity index using the R Phyloseq library [11]. The Good's coverage was estimated using a Perl script according to the formula: 1-(singletons/total reads). Sequences were taxonomically labeled following a sequence identity strategy by Blastn with the Megablast parameters against a database based on SILVA and curated with RDP and GG, which is available with the Metaxa2 v2.1.1 [12] software distribution. Taxonomic annotation was transferred to each of the representative sequences from rarefied OTUs (97\%). The heatmap in Fig. 2B was constructed in $\mathrm{R}$ using the heatmap2 function from gplots v3.0.1.1 library.

\section{Results}

The cenote's root bacterial communities, which include in our study the root episphere and the root endosphere of each of the characterized plant species, showed similar Chao and Shannon diversity indexes which both were higher than those observed in the cenote freshwater (Table 1). Beta diversity analysis showed that the cenote water microbial community is an outgroup in relation to the cenotes roots cluster. Within the latter, the Ficus obtusifolia microbial community was the most dissimilar (Additional file 1: Figure S1).

A deeper analysis of shared taxa between water and plant-associated microbial communities, revealed 2588 OTUs common to all three roots that were absent in the cenote freshwater. Only 488 OTUs were also shared among the cenote water and all plant roots (Fig. 2). The OTUs present in roots represented 219 distinct genera from 107 families, sustaining the observation of greater microbial diversity. Despite these high number of shared OTUs ( 2588 out of 27,541 or $9.40 \%$ ), the relative abundance varied in sampled plant roots (Fig. 2). These results reinforce the idea that microbiome found in plant roots immersed in aquatic ecosystems are influenced by the host.

Increasing evidence shows that root exudates recruit, nurture or repel different types of microorganisms in soil-based rhizospheres [13, 14]. However, information of aquatic root microbial communities and knowledge regarding how these are shaped in aquatic environments remain scarce. We investigated the composition and diversity of the bacterial and archaeal communities 
(a) Microbial diversity at phylum rank

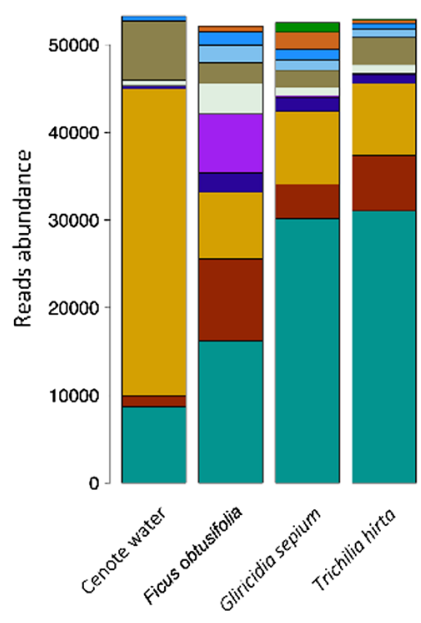

(c)

\section{OTUs $(97 \%)$ richness}

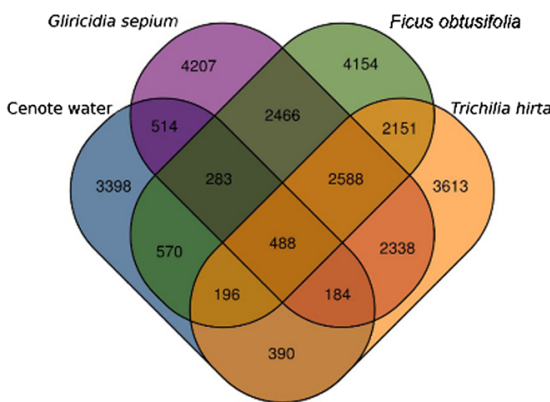

(b)

E Chlamydiae

ㄷ. Chloroflexi

ㅁ Planctomycetes

ㄷ Actinobacteria

$\square$ Bacteroidetes

- Cyanobacteria

Deltaproteobacteria

- Betaproteobacteria

Gammaproteobacte

- Alphaproteobacteria

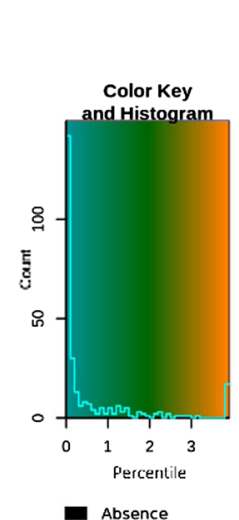

Color code for phylum rank

Proteobacteria

Actinobacteria

Bacteroidetes

Cyanobacteria

Verrucomicrobi

Chioroflexi
Most abundant phylotypes at genus rank

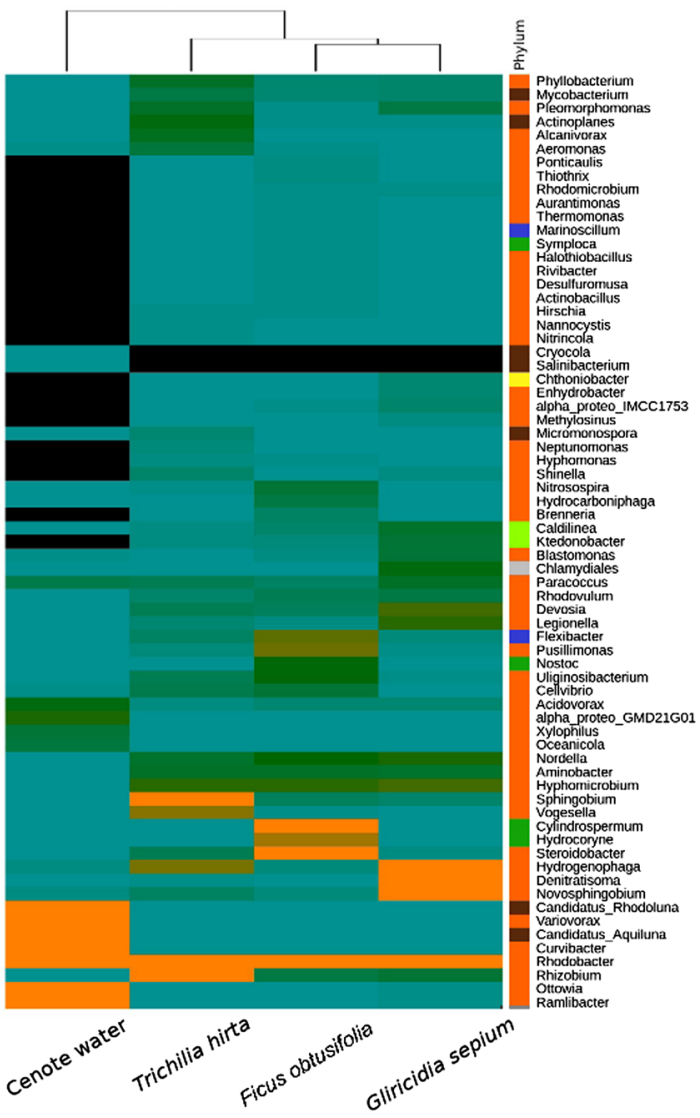

Fig. 2 Structure of the root microbial communities from plant roots and freshwater collected in April 2013 from the Sac Actun cenote in the Yucatan peninsula, Mexico. (A) Reads abundance by sequence identity to prokaryotic references depicted at phylum rank. Low abundance phyla list is available in Additional file 2: Table S1. (B) Comparison of the most abundant genera found in cenote water and plant roots. The color scale represents the genera abundance distribution in percentiles. (C) Venn diagram representing unique and shared OTUs (97\%) between samples of water and plant roots

Table 1 Analysis of bacterial and archaeal OTUs diversity in roots and in the cenote's water

\begin{tabular}{|c|c|c|c|c|c|c|c|}
\hline Sample & Total reads & $\begin{array}{l}\text { Average read } \\
\text { length (bp) }\end{array}$ & $\begin{array}{l}\text { Prokaryotic } \\
\text { OTU's } \\
(97 \%)\end{array}$ & Chao1 & Sampling effort & Shannon index & Good's coverage \\
\hline Cenote water & 104,722 & 209.79 & 6,023 & 8,549 & 70.45 & 5.75 & 0.951 \\
\hline Gliricidia sepium & 136,573 & 184.96 & 12,896 & 19,838 & 65.01 & 8.23 & 0.884 \\
\hline Ficus obtusifolia & 131,302 & 171.42 & 13,068 & 17,824 & 73.32 & 8.37 & 0.896 \\
\hline Trichilia hirta & 112,632 & 178.77 & 11,948 & 17,253 & 69.25 & 7.99 & 0.899 \\
\hline
\end{tabular}

colonizing the roots of three sympatric plant species living immersed in the freshwater of the cenotes by highthroughput taxonomic profiling. This survey provides data helping botanists and microbiologist better understand root/microbiota interactions in non-classical environments.

\section{Conclusions}

Studies of the ecological effects of root microbiomes in plants had been primarily performed in soil environments. Consequently, the cenotes offer a unique opportunity to expand our understanding of root-microbial associations beyond those interactions occurring in most 
terrestrial ecosystems. Our finding that each root microbiome analysed here has a distinct and highly diverse microbial community profile, that is not shared with the one from the surrounding freshwater, motivates further investigations. Future comparisons should include comparisons of root microbiomes of the same host species in purely terrestrial ecosystems, as well as in the cenotes, with the purpose of distinguishing the effects of host selection from those imposed by the habitat (soil vs. aquatic). Moreover, separation of "rhizosphere" from "root endosphere" in this ecosystem may facilitate the identification of microbial groups that clearly respond to root exudates and those that may be of vertical transmission. Finally, evaluation of the fungal communities associated with the roots could also shed light on the role of fungal symbionts, such as mycorrhizal fungi, in the adaptation of plants to this unique niche. In summary, our data strongly suggest that sympatric plants roots living immersed in the freshwater of cenotes harbor a distinct and highly diverse prokaryotic community, which seems to be influenced by the host and its hydroponic-like growing conditions.

\section{Limitations}

One limitation of our study was the lack of biological replicates, which are necessary for quantitative estimations of host selection and microbial diversity. However, finding biological replicates in the unique niche of the cenotes is extremely difficult. Since there is no indication aboveground of what plants have roots reaching the water in the cenotes there is no way to know what caves must be explored to find more roots. Moreover, the access to many cenotes is so difficult that only highly qualified divers can reach them. Consequently, a systematic exploration of the underground aquifer to locate several roots of the same species is very complicated.

\section{Supplementary Information}

The online version contains supplementary material available at https://doi. org/10.1186/s13104-021-05746-x.

Additional file 1: Figure S1. Beta diversity analysis.

Additional file 2: Table S1. Low abundance phyla list.

Additional file 3: Table S2. PCR conditions for DNA amplification. Table S3. Plant species identification, GenBank accesion numbers.

\section{Acknowledgements}

We thank Felipe Fernandez Solis and Robbie Schmittner for their kind help during the collection of the samples.

\section{Authors' contributions}

F.V. conceived the study and collected the samples. LMV, PRE and PT performed DNA extraction, PCR amplification and 16S rRNA sequencing and identified plant species by DNA barcode. AEZ and ASF constructed microbial communities by applying bioinformatics to the $16 \mathrm{~S} r \mathrm{RNA}$ sequencing raw data. RR processed satellite imagery and produced remote sensing maps. AEZ, ASF, LPPM and FV wrote the report with input from all authors. All authors read and approved the final manuscript.

\section{Funding}

Open Access funding enabled and organized by Projekt DEAL. This research was financially supported by the Foreign Postdoctoral Researcher program of RIKEN.

\section{Availability of data and materials}

Plant species DNA barcodes are available at the website of GenBank for the $r b c L$, matK and psbA-trnH regions under the numbers: Ficus obtusifolia, MK643034, MK643037 and MK643040; Gliricidia sepium, MK643035, MK643038 and MK643041; Trichilia hirta, MK643036, MK643039 and MK643042. 16S rRNA sequences are available at the NCBI website under the BioProject database number PRJNA559701 (https://www.ncbi.nlm.nih.gov/bioproject/?term= PRJNA559701).

\section{Declarations}

Ethics approval and consent to participate

Not applicable.

Consent for publication

Not applicable.

\section{Competing interests}

Not applicable.

\begin{abstract}
Author details
${ }^{1}$ Instituto de Biotecnologia, Unidad Universitaria de Secuenciacion Masiva Y Bioinformatica, Universidad Nacional Autonoma de Mexico, Cuernavaca, Mexico. ${ }^{2}$ LaNaBio, Instituto de Biologia, UNAM, Mexico City, Mexico. ${ }^{3}$ Instituto de Investigaciones Biomedicas, UNAM, Mexico City, Mexico. ${ }^{4}$ Departamento de Ingenieria Genetica, Centro de Investigacion Y de Estudios Avanzados, Irapuato, Mexico. ${ }^{5}$ Macroecology and Society, German Centre for Integrative Biodiversity Research Halle-Jena-Leipzig, Leipzig, Germany. ${ }^{6}$ Molecular Interaction Ecology/EcoMetEoR, German Centre for Integrative Biodiversity Research Halle-Jena-Leipzig, Leipzig, Germany. ${ }^{7}$ Institute of Biodiversity, Friedrich Schiller University Jena, Jena, Germany.
\end{abstract}

Received: 11 December 2020 Accepted: 18 August 2021

Published online: 07 September 2021

\section{References}

1. Perry E, Velazquez G, Socki R. Hydrogeology of the Yucatan Peninsula. In: Gomez A, Allen M, Fedick S, Jimenez J, editors. The Lowland Maya Area: three millennia at the human-wildland interface. Boca Raton: CRC Press; 2003. p. 115-38.

2. Rzedowski J. Vegetacion de Mexico. $1^{\text {a }}$ edicion digital. Comision Nacional para el Conocimiento y Uso de la Biodiversidad, Mexico. 2006.

3. Albanil A, Pascual R, Cruz L, Lopez M. Reporte del clima en Mexico. Servicio Meteorologico Nacional: 135 años de historia en Mexico. 2012. https://smn.conagua.gob.mx/tools/DATA/Climatolog\%C3\%ADa/Diagn\% C3\%B3stico\%20Atmosf\%C3\%A9rico/Reporte\%20del\%20Clima\%20en\% 20M\%C3\%A9xico/Anual2012.pdf.

4. Schmitter J, Comin F, Escobar E, Herrera J, Alcocer J, Suarez E, Elias M, Diaz V, Marin L, Steinich B. Hydrogeochemical and biological characteristics of cenotes in the Yucatan Peninsula (SE Mexico). Hydrobiologia. 2002;467:215-28.

5. Bauer P, Gondwe B, Charvet G, Marin L, Rebolledo M, Merediz G. Review: the Yucatan Peninsula karst aquifer. Mexico Hydrogeol J. 2011;19:507-24.

6. Romero L. Hallazgo arqueologico. Hay un cenote bajo el templo de Kukulkan. Gaceta UNAM, August 13th. 2015. p. 12-3.

7. Haney C, Ausubel F. Plant microbiome blueprints. Science. 2015;349:788-9. 
8. Doyle J, Doyle J. Isolation of plant DNA from fresh tissue. Focus. 1990;12:13-5.

9. Huerta-Cepas J, Serra F, Bork P. ETE 3: reconstruction, analysis, and visualization of phylogenomic data. Mol Biol Evol. 2016;33:1635-8.

10. Rognes T, Flouri T, Nichols B, Quince C, Mahe F. VSEARCH: a versatile open source tool for metagenomics. PeerJ. 2016;4:e2584.

11. McMurdie P, Holmes S. phyloseq: An R Package for reproducible interactive analysis and graphics of microbiome census data. PLOS ONE. 2013:8:e61217.

12. Bengtsson-Palme J, Angelin M, Huss M, Kjellqvist $S$, Kristiansson E, Palmgren $\mathrm{H}$, Larsson D, Johansson A. The human gut microbiome as a transporter of antibiotic resistance genes between continents. Antimicrob agents ch. 2015;59:6551-60.

13. Bais $\mathrm{H}$, Weir T, Perry L, Gilroy S, Vivanco J. The role of root exudates in rhizosphere interactions with plants and other organisms. Annu Rev Plant Biol. 2006;57:233-66.

14. Doornbos R, van Loon L, Bakker P. Impact of root exudates and plant defense signaling on bacterial communities in the rhizosphere. A review Agro. Sustain Dev. 2012;32:227-43.

15. Kambesis P, Coke J. The Sac Actun system, Quintana Roo. Mexico Bol Geol Min. 2016;127:177-92.
16. Levin R, Wagner W, Hoch P, Nepokroeff M, Pires J, Zimmer E, Sytsma K. Family-level relationships of Onagraceae based on chloroplast rbcL and ndhF data. Am J Bot. 2003;90:107-15.

17. Kress W, Erikson D. A two-locus global DNA barcode for land plants: the coding rbcL gene complements the non-coding trnH-psbA spacer region. PLOS ONE. 2007;2:e508.

18. Cuenoud P, Savolainen V, Chatrou L, Powell M, Grayer R, Chase M. Molecular phylogenetics of Caryophyllales based on nuclear $18 \mathrm{~S}$ rDNA and plastid rbcL, atpB, and matK DNA sequences. Am J Bot. 2002;89:132-44.

19. Sang T, Crawford D, Stuessy T. Chloroplast DNA phylogeny, reticulate evolution and biogeography of Paeonia (Paeoniaceae). Am J Bot. 1997:84:1120-36.

20. Tate J, Simpson B. Paraphyly of Tarasa (Malvaceae) and diverse origins of the polyploid species. Syst Bot. 2003;28:723-37.

\section{Publisher's Note}

Springer Nature remains neutral with regard to jurisdictional claims in published maps and institutional affiliations.
Ready to submit your research? Choose BMC and benefit from:

- fast, convenient online submission

- thorough peer review by experienced researchers in your field

- rapid publication on acceptance

- support for research data, including large and complex data types

- gold Open Access which fosters wider collaboration and increased citations

- maximum visibility for your research: over $100 \mathrm{M}$ website views per year

At BMC, research is always in progress.

Learn more biomedcentral.com/submissions 